\title{
Conflicting Goals In A Higher Education Environment
}

\author{
Jan Colbert, Eastern Kentucky University, USA
}

\begin{abstract}
Marie O'Shutt is the MBA Director, a mid-level management position, at an institution of higher education (a university). She inherited Amy, an underachieving administrative assistant (AA) when she was asked to take the MBA position. Marie has concerns related to ethics and integrity surrounding some of Amy's actions, including recording hours worked that cannot be substantiated. Marie's goal is to employ a productive AA in order to operate an efficient and effective MBA program. Amy strongly desires to retain in the position of MBA AA and to maintain the status quo of reporting hours worked at hours when the university was not open and which cannot be substantiated. Upper level management at the university; i.e., the Dean of Business and the Director of Human Resources, has a goal of wanting to avoid having Amy sue. Members of management in this institution of higher education appear to have conflicting goals and are not seeking goal congruence, and the issues involve integrity, ethics, and legal matters.
\end{abstract}

Keywords: Ethics; Higher Education; Human Resources; Integrity; Goals; Goal Congruence; Conflicting Goals

\section{LEARNING OBJECTIVES}

ourses and levels for which this is intended are graduate-level courses, such as classes within MBA (Masters in Business Administration), MPA (Masters in Public Administration), Masters in Accounting programs and upper-level undergraduate courses, such as Leadership and Responsibility, Ethics, Human Resources, and Auditing and Assurance Services.

1. The first learning objective is to expose students to a real life scenario in which managers at different levels in an organization are working toward different goals.

2. The second learning objective, related to the first, is for students to comprehend through a real-life scenario, that, for an organization to be effective, it is critical for the entire organization to have congruent goals.

3. The third learning objective is for students to understand that the goal of avoiding conflict and a lawsuit can lead to unethical and possibly illegal actions.

\section{CASE SYNOPSIS}

Upper-level management and mid-level management may not always have the same goals. This case provides a real life example, in a higher education setting, of mid-level management; i.e., the MBA Director, having a goal of effective and efficient operations, while upper-level management's (the Dean of Business and the Director of Human Resourced) goal is to avoid conflict and prevent a lawsuit.

The administrative assistant (AA) for the MBA Director was not calling in to work when absent, was claiming hours worked for which the MBA Director had no knowledge, and was negligent in her duties and underperforming.

While the MBA Director wanted the AA to leave the position so another competent and reliable individual could be hired, the Dean and the Director of Human Resources (upper-level management) were afraid of the AA suing the university and wanted to maintain the AA in her position. The MBA Director had serious qualms about 
approving the timesheets for the AA for time she may not have worked, fearing it was unethical and possibly illegal to do so. Further, the MBA Director, who was a CPA and a PhD in accounting, was spending her time either correcting many of the AA's past blunders or performing current AA duties when the AA was out. The MBA Director was frustrated at this inefficient and ineffective use of her skills and time.

\section{RESEARCH METHODS}

The author was an administrator at an institution of higher education for a period during which time she encountered a situation similar to that described. The identity of the parties involved has been protected by changing the names of all individuals and entities.

\section{INTRODUCTION}

Marie O'Shutt, who held a PhD in accounting and was a CPA, had only been a professor at the large regional public university for two years when she was named Director of the MBA program. Marie took over the duties of MBA Director when the former Director, Lynne Law, an attorney, became in-house University Counsel.

On the organizational chart of the university, the MBA Director is a mid-level management position. The Dean of Business, at a higher level of management, had authority and responsibility for all positions in Business (administrators, faculty, and staff, including administrative assistants). When appointing Marie as MBA Director, the Dean chose to retain the administrative assistant (AA) for the MBA program, Amy Adams, in the MBA office. While Marie, the new MBA Director, did not have administrative experience, she had taught a variety of MBA courses at this university as well as at a sister institution in the same state.

\section{History of the MBA Office}

Amy's years as the AA in the MBA office had begun when she worked for the MBA Director prior to Lynne Law. When that MBA Director moved on to another university and Lynne filled his spot, Amy provided continuity in the MBA office. As Lynne's time as MBA Director continued, she became involved in a number of time-consuming university-wide committees.

Also, Lynne had two teenage sons on traveling sports teams. Over time, Lynne gave Amy increasing duties and responsibilities. Amy enjoyed the autonomy and relished the additional power and control. While Amy lacked a college education, she was free to make many MBA program decisions herself. She documented little and was reticent to inform others of the workings of the MBA program. Counsel.

After three years as MBA Director, the President of the university appointed Lynne as in-house University

The Dean, who had known Marie for many years from a previous university and was close friends with her, asked Marie to step in as MBA Director. Marie was devoted to the MBA students and the program. While she felt her skills were not in the administrative arena, she felt she could not let the Dean and the MBA students down and she reluctantly accepted the half-time appointment.

Amy was disappointed; she herself had hoped to have been named MBA Director. Although she clearly did not meet the minimum requirements, she was distressed to not have been appointed MBA Director by the Dean. Further, she noted to faculty and staff that she "did not know if she could work with Marie."

\section{Current Organization of the MBA Office}

Because the MBA Director's position was half-time, Marie continued to teach, albeit fewer classes. Like any tenured faculty member fulfilling administrative duties, Marie could return to full-time teaching if and when she might elect to step down from the position of MBA Director. 
When discussing the MBA Director position with Marie, the Dean had noted the challenges of managing Amy, who had always been a slow and sloppy worker. The AA's office and files were in constant disarray and she was typically far behind in her duties. Her responses to inquiries by students, faculty, and administrators alike were delayed and often at the last moment. She increasingly gave answers to faculty and administrators which were wrong and provided MBA students with incorrect direction regarding coursework to take and other matters of consequence in completing the MBA requirements. It was not unusual for Amy's voice mailbox and her email inbox to both be full, thus making it difficult for faculty, students, potential students, the Dean's office, and others to communicate with her. Her desk was piled high with paperwork, as were the shelves in her office, and she could not appear at a meeting on time. Having her retrieve a document or an email was a time-consuming experience. Amy's performance was well-known not only in the MBA program and the Dean's office, but throughout the College of Business.

Lynne Law, the MBA Director prior to Marie, had been at the university many years by the time she became MBA Director. Further, her husband, in another College in the university, held a high-ranking position. Together they knew many people in the university and the community. Due to this history and the connections, Lynne had a deep comprehension of the systems and the people of the institution; she was able to effectively work around the slow-paced Amy in accomplishing the tasks of the MBA program. Further, for reasons unknown to others, although Lynne privately complained frequently about Amy, Lynne gave her glowing evaluations at each written annual review.

When Lynne became in-house University Counsel and the Dean asked Marie to become MBA Director, Marie had, by necessity, to rely on Amy for knowledge and history of the program and the students. After only a few months, Marie became concerned about the effectiveness of Amy's work.

\section{Amy's Personal Situation}

Over a period of several years, just prior to Marie becoming MBA director, both of Amy's parents had been quite ill. Amy and her four siblings had not agreed on their care. The two camps had been involved in two separate legal cases spanning approximately three years. Amy had won both cases and was caring for the mother and father in her home. Still, the stress was palpable.

Besides the legal issues involving her parents, Amy and her husband of many years, Arthur, had divorced around the time of the transition from Lynne to Marie as MBA Director. Despite the divorce, Arthur, after losing his job, had been permitted to move back in with Amy. Further, her three adult children, none of whom worked, were living with her. To add to her workload, Amy attempted to take two college-level courses per semester.

During the time that Lynne Law had been the MBA Director, she had approached the Dean of Business, Roger Roberts, about the possibility of Amy working flex hours. This arrangement, to accommodate Amy with caring for her aging parents, was approved. It continued when Marie became MBA Director.

Once she was allowed flex-time, Amy began coming in to work later and later in the day; there was no set time when she was to start work. Sometimes, Amy would commence her work day after the official close of the university. She noted on her timesheets that she worked into the evenings, but no one really knew when or if she was working. Her hours were unpredictable at best. In addition, she sometimes decided she would work from home without consulting anyone at the university.

\section{Where Is Amy? When Is She Working?}

When Marie O'Shutt became MBA Director, the hours that Amy did or did not work became a source of contention between the two. Since she did not know when or if Amy was working, Marie had increasing qualms about approving Amy's timesheet. Marie, a CPA, was particularly concerned with the legal and ethical ramifications of approving time for a state employee when she did not really know if and when Amy worked; Marie felt her integrity was being compromised. 
Besides the working time matter, Marie was not able to obtain student and program information from Amy or consult with her since Amy was not at work during the times that the university was open and documented little. Further, it became evident that Amy did not want Marie to gain an understanding of the various MBA processes or systems and was withholding information.

To further add to the challenge of the MBA office operating effectively, when her parents were hospitalized or became more ill, Amy might or might not call in to inform Marie and the College of her absences. If she called in, it would not be until late in the afternoon. In the meantime, the work of the MBA office was suffering more and more. The little work Amy performed was sloppy at best and often had to be followed up on and corrected. Marie, the MBA Director, spent most of her time either doing Amy's work or correcting it. Marie, who had hoped to move the MBA program forward with several initiatives, was stymied.

Amy felt that she should not have to inform Marie or the College of her hours. When Marie asked if a time each day could be established when Amy would let Marie know if and when she was coming in to work, Amy complained to the Dean that Marie was not being compassionate. Amy refused to take vacation or sick leave to care for her parents, claiming she was performing work from home or in the evenings. She became increasingly angry with Marie and repeatedly took her complaints to two members of upper-level management, the Dean and to the Director of Human Resources (HR), Greg Bailey. Both of these individuals listened to her during multiple meetings. Criticism was heaped upon Marie, the relatively new MBA Director.

\section{Who Wants What?}

Dean Roberts, Marie, and Greg Bailey met a number of times regarding Amy's performance and attendance issues over a period of weeks. Greg expressed concern that the prior years' evaluations of Amy, given by Lynne Law, had been glowing, while Marie was presenting quite a different picture of her performance. Also, he repeatedly noted that he was 'trying to keep peace in the (university) family.' In turn, the Dean was well known for attempting to avoid conflict and worked hard to stay neutral.

Marie stressed that her responsibility was the efficient and effective operation of the MBA office and her desire to move the program forward; she felt Amy was not only hindering that effort, but actively working against the program's operations. Amy pressed for the status quo - working when and if she desired, with no notice of absences while collecting full pay and benefits.

\section{Administrative Leave}

A few months after taking over the MBA duties and after repeated discussions with Amy about her time at work and numerous performance issues, Marie convinced the Dean to place Amy on administrative leave. Despite Amy's vigorous protests, this was accomplished.

While Amy was on administrative leave, Marie handled all MBA issues. As time passed, more and more issues that Amy has created or allowed to persist or attempted to conceal became apparent to Marie.

A few weeks after being placed on administrative leave, Amy's parents passed away, within nine days of each other. Shortly after their deaths, Amy demanded to come back to work in the MBA office.

\section{Amy Returns}

Marie, burdened with dealing with the many problematic issues which Amy had created and not wanting back an employee with the behavior which Amy had previously displayed, did not want Amy to return to the MBA office. The MBA Director was opposed to Amy incorrectly providing advice to students, undermining Marie's efforts to advance the MBA office, and working at hours determined by Amy. She also did not want to be put in the position of possibly being expected to approve hours that she did not know that Amy worked, due to the legal and ethical issues involved. 
On the other hand, the Dean and the Director of HR, both noting they were attempting to avoid conflict and a possible lawsuit by Amy against the University, were adamant that Amy should return; she had threatened to sue the university if she was not permitted to return.

The Dean chose to permit Amy to return to a position at the university. Only because Marie protested so much that she did not want Amy back in the MBA office was Amy not permitted to return to her previous position. At Marie's suggestion, the Dean allowed Amy to return as a receptionist in the Dean's office, a position she had held some years earlier. However, Amy was furious at being a receptionist rather than the MBA AA. While acknowledging Amy's deficiencies as an employee, the Dean voiced his opinion to Marie that she was being 'hardheaded' regarding her being strongly opposed to Amy returning to the MBA office. By this time, a schism, with the Dean and the Director of HR on one side and the MBA Director on the other, had developed.

While the Dean allowed Amy to return as a receptionist in the Dean's office, he indicated to her that the receptionist position was available for only about four and one-half months and that she would not be returning to the MBA office. He advised Amy to search for other positions within the university, or external to it. Amy refused. She was adamant that she would return to the MBA office as the AA.

In the meantime, the MBA office was operating without an AA and Marie continued to perform the AA duties. The Dean, who controlled the budget of the College, told Marie repeatedly that, as long as Amy held the receptionist position, there was no money available to hire an MBA AA. Thus, Marie, a CPA and PhD in accounting, spent most of her time performing administrative assistant duties; she became increasingly frustrated.

Lynne, the former MBA Director who became University Counsel, kept in close contact with Amy during this period; they were good friends and spoke at least once a week. Amy had long sought advice from Lynne; in turn, Lynne enjoyed rescuing Amy from various precarious legal situations (parents and siblings, divorce, employment). Lynne strategized with Amy and helped her considerably behind the scenes.

\section{Frustration}

Marie found it increasingly difficult to effectively discharge the duties of MBA Director. Without an AA, she was spending time performing clerical duties. To avoid conflict and reduce the possibility of a lawsuit, both the Director of HR and the Dean of the College of Business felt Amy should return to the MBA office. Marie, wanting the office to perform efficiently and effectively, was adamantly opposed. Also, Marie was frustrated that the MBA office was not moving ahead on new initiatives and the months of handling the various Amy issues and the emotional energy had taken valuable time and effort.

Marie is trying to focus on moving forward and strategizing. She is trying to accomplish her goal of operating an effective and efficient MBA program while accommodating the goal of the Dean and the Director of HR to avoid conflict and reduce the risk of a lawsuit. Marie wants to do not only what is legal, but what is ethical, and she wants to act with integrity. Although Amy is a receptionist currently in the Dean's office of the College of Business, Marie is considering whether she should allow Amy to return to the MBA office in order to placate the Dean and the Director of HR (and Amy). Also, she is considering other alternatives and their advantages and disadvantages not only to her, but to the MBA program and to the University. She understands that conflicting goals is not beneficial to an organization and that an entity should strive towards goal congruence.

\section{DISCUSSION QUESTIONS}

1. Who are the key actors?

2. State the problem concisely.

3. What are the major issues in the case?

4. Determine management's goals in the case.

5. Analyze the facts of the case as they contribute to the problem.

6. Is it ethical for Marie to sign Amy's timesheets?

7. Critique the Dean's actions/decision in the case.

(C) 2012 The Clute Institute http://www.cluteinstitute.com/ 
8. Did anything occurring prior to Marie taking over as MBA Director contribute or lead to the current dilemma?

9. What are Marie's options?

10. Consider alternatives and note the advantages and disadvantages of each alternative.

11 Choose a solution, based on the evidence.

12 If you were Marie, what would you do?

\section{AUTHOR INFORMATION}

Dr. Jan Colbert is a Professor of Accounting at Eastern Kentucky University in Richmond. She is a CPA and a CIA. She has served on the Kentucky State Board of Accountancy and on the Board of Directors of the Kentucky Society of CPAs and has chaired the Audit Committee of the AICPA Exams team. She has published a number of articles on topics such as corporate governance, ethics, sampling, internal control, and financial literacy. E-mail: jan.colbert@eku.edu 


\section{TEACHING NOTES}

\section{Conflicting Goals in a Higher Education Environment}

\section{DISCUSSION QUESTIONS AND ANSWERS}

\section{Who are the key actors?}

Marie O'Schutt, the current MBA Director

Amy Adams, the MBA administrative assistant

Lynne Law, former MBA Director and current University Counsel

Roger Roberts, the Dean of Business

Gary Bailey, the Human Resources Director

\section{State the problem concisely.}

In her role as MBA Director (mid-level management), Marie does not have the support of the Dean and the HR Director, who are both higher-level management. In this situation, Marie faces conflicting choices:

- If Marie does not permit Amy to return to the MBA office, she will not have an AA, as the Dean controls the budget and states that there are no funds for an MBA AA as long as Amy remains in the receptionist position. Marie, a $\mathrm{PhD}$ in accounting and a $\mathrm{CPA}$, would have to continue to perform clerical duties. This is not a good use of her talents.

- If Marie does permit Amy to return to the MBA office, she will have to follow up and correct her work and tolerate Amy's plodding pace. Additionally, she will face the ethical dilemma once again of approving timesheets for Amy when she is not sure if Amy worked or the hours she worked.

3. What are the major issues in the case?

The university personnel do not agree on how to handle the situation involving Amy Adams. Marie, the MBA Director, wants an AA who provides information and supports the work of the office and informs her of absences. Amy, seeking power and control, chooses not to provide information to Marie and not to inform her of her absences.

Amy wants to return to her the MBA office in the AA position, refusing to look for another position within the university or external to it, while Marie would like an AA who is reliable, effective, and efficient.

Greg Bailey's goal is for the university to avoid a lawsuit initiated by Amy.

The Dean's goal is to avoid conflict.

Lynne Law, the former MBA Director and current University Counsel, did not document Amy's poor performance over a number of years and in fact, gave her glowing evaluations.

Marie was not comfortable signing timesheets for Amy when she was not sure of the hours worked.

4. Determine management's goals in the case.

The Dean and the Director of HR are upper-level management. Both of them have the goal of reducing the possibility of Amy filing a lawsuit against the university. Thus, they both want Marie to allow Amy back in the MBA office as the AA. 
In her position as MBA Director at the university, Marie is middle management. Her goal is to serve the MBA students, the faculty, and the administration in accomplishing work in the MBA office.

Since Amy was not reliable and not communicative about her hours and her work was of poor quality, Marie does not want Amy to return to the MBA office. Further, Marie strongly believes there is an ethical, and perhaps a legal, issue involved when being asked to approve the time worked for Amy when she is not sure of the hours worked.

\section{Analyze the facts of the case as they contribute to the problem.}

Marie, in charge of the day-to-day affairs of the MBA office, is stymied, as upper-level management (the Dean and the Director of HR) want her to welcome Amy back to the MBA office.

The Dean admits that there are challenges associated with Amy as an employee. Still, he, as well as the HR Director, wants to avoid a lawsuit and conflict; thus, they want Amy to be allowed to return to the MBA office, as she wishes to do.

The annual evaluations of Amy's work, completed by Lynne Law, contribute to the dilemma.

6. Is it ethical for Marie to sign Amy's timesheets?

It is not ethical for Marie to approve Amy's timesheets if she does not know if or when Amy actually worked. Further, such an approval may raise a legal issue.

\section{Critique the Dean's actions/decision in the case.}

The Dean, responsible for all faculty and staff in the College of Business, must continue to work with HR in hiring and employment issues. Also, he traditionally tries to avoid conflict. Because of the threat of Amy filing a lawsuit, he tried to reduce the chances of that occurring by giving her a receptionist position in the Dean's office.

Regarding the work of the MBA office, the Dean hampered the work of the MBA office by not providing resources to hire a temporary or permanent AA.

8. Did anything occurring prior to Marie taking over as MBA Director contribute or lead to the current dilemma?

The annual evaluations by Lynne Law, former MBA Director and current University Counsel, of Amy's performance contributed greatly to the current dilemma. Because Amy's evaluations in previous years were glowing, Greg Bailey, the HR director, did not support taking any action to address the current situation and, in fact, was in favor of allowing Amy to return to the MBA office.

Also, by allowing Amy to work flex-time, Lynne, the previous MBA Director, and the Dean contributed to the current dilemma. Amy became used to working hours which she chose. Further, Lynne approved her timesheets without question. When Marie became concerned about approving Amy's timesheets due to not having knowledge about her actual hours worked, Amy became incensed.

\section{What are Marie's options?}

Marie is being criticized by both the Dean and the Director of HR and yet is responsible to accomplish the work of the MBA Office. Her options include:

- $\quad$ stay in the MBA Office as MBA Director, performing clerical duties and waiting in hopes of being able to hire an AA at some point in the future 
- $\quad$ stay on as MBA Director and try to persuade the Dean to allow hiring of a temporary employee until an AA can be hired at some point in the future

- $\quad$ step down from the MBA Director position and return to full-time teaching

10. Consider alternatives and note the advantages and disadvantages of each alternative.

- If Marie does not permit Amy to return to the MBA office, she will not have an AA. The Dean controls the budget and states that there are no funds for an MBA AA, as long as Amy remains in the receptionist position. Marie, a $\mathrm{PhD}$ in accounting, would have to continue to perform clerical duties.

Advantage: If Amy does not return to the MBA office, she is not performing work which Marie then has to follow up on and correct. Further, Marie will not be asked to approve timesheets that she is not comfortable signing.

Disadvantage: By not permitting Amy to return to the MBA office, Marie will have to continue to perform clerical duties. Such work by Marie, who holds a $\mathrm{PhD}$ in accounting, would be demoralizing to her and not a good use of her time and talents. Because Marie is performing clerical duties, the MBA program cannot move forward with new initiatives.

- If Marie does permit Amy to return to the MBA office, Marie will have to follow up and correct her work and tolerate Amy's plodding pace. Additionally, she will face the ethical, and potentially legal, dilemma once again of approving timesheets for Amy when she is not sure if Amy worked or the hours she worked.

Advantage: By allowing Amy to return to the MBA office, Marie would comply with the desires of upper-level management (the Dean and the HR Director), who believe that by not allowing Amy to return to the MBA office, there is a risk of a lawsuit.

Disadvantage: Marie would be asked to approve Amy's timesheets. With Amy's history of submitting time for hours that Marie was not certain had been worked, Marie would again be faced with an ethical, and possibly legal, dilemma. Further, she would have to monitor and correct Amy's work.

- $\quad$ Marie could step down from the MBA Director position and returning to full-time teaching.

Advantage: Marie steps out of the conflict. She is thus avoiding the ethical and possibly legal dilemma regarding the timesheets. The Dean must then address the future administration of the MBA office.

Disadvantage: If Marie steps out of the MBA Director role, the continuity for the MBA program is adversely impacted. She had not been in the position long and another change in leadership in the program would impact the smooth workings of the MBA office. In particular, students would be adversely affected.

\section{Choose a solution based on the evidence.}

Marie is faced with an untenable situation. Upper-level management strongly desires Marie to welcome Amy back to the MBA office. Marie, responsible for the MBA office, is concerned with Amy's poor quality of work and with her not calling in her absences. Also, Marie has an ethical concern with being asked to approve hours for Amy on her timesheet which Marie is not sure that Amy worked. Thus, Marie should step down from the position of MBA Director and return to full-time teaching. This alleviates her ethical dilemma. Albeit not in the best interest of the MBA program, the choice paves the way for the Dean to address the issues in the MBA office. 


\section{If you were Marie, what would you do?}

Marie is in a difficult position. She does not have the support of the Dean or the Director of HR who are both higher-level management at the university. The situation makes it difficult to administer the MBA program. She should strongly consider stepping down from the position of MBA Director and return to full-time teaching. 